\title{
Social and Educational Inclusion in Schools and Their Communities
}

\author{
Ghazala Bhatti
}

\section{Introduction}

This chapter is about inclusion and inclusive education. It looks at how sociologists have defined inclusion and how educationalists have sought to develop ideas which have implications for students' academic and professional development. The EDIC + project helped to create learning spaces for individuals in educational institutions, such as schools and universities. Shared learning experiences provided opportunities for working with diversity and difference and for professional networking. Participating students came from diverse backgrounds and from many countries across the world. This chapter considers the theoretical background which led to the development of the module at Bath Spa University. It also presents student evaluations of the module trialled before the final schedule of the Masters level module was put together.

\section{Democracy and Human Rights}

Although education has been declared a basic human right for quite some time now, 262 million children and youth were not in school in 2016 (UNESCO, 2016). According to the United Nations 57 million children in poor countries have no schools. These are shocking figures. When some children living in poverty do manage to access basic schooling, it does not mean they will acquire adequate life skills which lead either to educational fulfilment or decent employment. The developing world faces challenges mostly because of economic reasons and the capability people have to achieve what is best for them (Sen, 1980).

Economically advanced countries also struggle with inclusion, when for example they consider the education of the gypsy, Roma, traveller and indigenous communities (Gobbo, 20o9; Levinson \& Hooley, 2014). In some countries such as in England there are faith-based schools - the Catholic, Jewish and Muslim schools. Questions have been raised about their contribution to society and role in inclusion/exclusion(Short, 2002; Jackson, 2006). Is it the shortcomings

(C) KONINKLIJKE BRILL NV, LEIDEN, 2019 | DOI: 10.1163/9789004411944_004 
of the state school system or society's failure to include everyone that lead to the setting up of different types of schools? Often those who are not fluent in the dominant language of a country are at risk of being excluded from engaging in school and the wider society (McEachron \& Bhatti, 2015). Researchers have documented the connection between heritage, culture, identity negotiation and the important role language acquisition and language maintenance play in the lives of children and young people. Blackledge and Creese (2010) have looked at the negotiation of language in institutional settings. Teacher training courses may not routinely heighten teachers' awareness, and not all teachers are knowledgeable about this important aspect of children's identities. Osler and Starkey (2010) have raised the issue of teachers and human rights education.

All of these examples show that there are many dimensions and layers of exclusions. Inclusive education aims to work for all in a way that can help society develop. How to do this successfully is a serious concern for many educationalists. So what does equity really mean in different contexts and what can inclusive education achieve? Can decisions arrived at through international consensus (e.g. UNICEF, UNESCO) be agreed upon as democratic decisions which are enforceable because they benefit a majority of people educationally? The answers are not easy. Inclusion remains an aspiration, and Inclusive Education is the means through which that aspiration can be realized. Its role is pivotal for present and future educational endeavours.

Julie Allan (2005) has named Inclusion 'an ethical project'. Not to be inclusive is to be unethical. Osman (2015) comments on values in education which offer 'pedagogies of hope' resulting in a

growing interest in inclusion and inclusionary practices (...) fuelled by the increasing criticism of tokenism in inclusion accompanied by significant advances in our knowledge about inclusive philosophies and pedagogies. (Osman, 2015, pp. ix-X)

Although this quotation is about past injustices and indifference to the educational destinies of children and young people in South Africa, this is not true only of South Africa. Marginalized communities and excluded children and young people exist everywhere, as demographic changes ensure a constantly shifting landscape. One current example of this is the education of refugees in Europe and how that is being handled in different countries. The local situation matters, as do policy and structural issues at the national level. Political will, resources and capability (Sen, 1993) for positive change must decide whether a school or a community responds to the need for inclusion. This is a matter for social justice in its broadest sense. 
Social justice for educationalists is not just about advancing theoretical knowledge and analytical understandings. It is also about interrogating practice in real educational settings which challenge prior assumptions (Griffiths, 2003). For social justice in education, the social, cultural, emotional and political contexts are as relevant as social structures and institutional practices. (Bhatti \& Leeman, 2011, p. 131)

How can social justice be made to work for the many? Young $(1990,1996)$ states that there can be no justice unless structural inequalities are questioned and the idea of a homogeneous public is challenged to include culturally plural groups. An inclusive participatory framework which looks critically at the white male norm would make spaces for others to contribute to the social and public good. This is a reminder of the chasm between good intentions and everyday realities for many people. Unless challenged, institutional practices will continue to reinforce and reinvent inequalities in education because of many factors such as ethnicity, social class and gender. Most societies would aim to maintain certain values and a certain standard of what is desirable for the public good.

Should each country teach its own special values to children? Are these different from the values being taught everywhere else? In Britain the advice issued by the Department of Education to all maintained schools asked them to 'promote the fundamental British values' (DfE, 2014, p. 4).

This has caused much discussion among educators and academics. It is seen as

... a response to fears of extremist religious Ideologies, terrorism and Muslim sharia law, and on page 5 of the guidance a reference is made to the reissued 'Prevent' strategy (Home Office, 2011) which actually defines extremism as 'vocal or active opposition to fundamental British values, including democracy, the rule of law and mutual respect and tolerance of different faiths and beliefs' (...) At a time when the United Kingdom is threatened with break-up, and a possible withdrawal from the European Union, and with the 'end of Empire' (...) what actually constitutes British values is highly debatable and cannot be reduced to a three-line slogan. (Tomlinson, 2015, p. 10)

\section{For Vini Lander}

Whilst there may be popular and political consensus with this list of values, the claim that they are wholly British is troublesome and in an 
attempt to forge cohesion, the unintended effect, but some (Hoque, 2015) would argue intentional effect, has been to create notions of insider-outsider citizen, or as Taras (2013, p. 420) notes, 'the subaltern internal others' or the stranger within, a stratification of citizenship into those who really belong, namely the indigenous majority, those who can belong, namely those of minority ethnic heritage who have assimilated or integrated and those who really do not quite belong, or those we tolerate up to a point, namely the Muslim 'other'. (Lander, 2016, p. 275)

This overt politicization of educational spaces has caused researchers to look more deeply at the meaning and implications of these values. Janmaat reports 'levels of support for fundamental British values (FBVs) among 23 year olds are already very high and do not differ between the white British majority and various minority ethnic groups' (Janmaat, 2018, p. 251). Sant and Hanley (2018) suggest that teachers' own positions will affect how they teach. This will depend on educators' understanding of the nation as an entity or as a social construct, and it will also depend on whether their own understanding of national identity is open or closed to other interpretations.

Panjwani (2016) summarised four inter-related strands of criticisms against FBVs which show the complexity facing educators and researchers. Documenting what Muslim teachers make of FBVs, he found that despite their criticisms of FBVS

Muslim teachers did not see any incompatibility between FBVs and their conception of Islamic values ... teachers' responses reflect Rawls 'overlapping consensus' and situates the roots of this consensus in contemporary Muslim intellectual history and the modernist reforms ... teachers' responses problematise the essentialised understanding of terms such as 'Islam' and 'the West' and indicate the interpretive and open-ended nature of cultures. (Panjwani, 2016, p. 329)

Are children of minority ethnic or mixed-race or Muslim backgrounds seen as outsiders? Which other countries teach 'fundamental values' in the same way? At a time when Brexit is being debated in a climate of national soul searching about 'what does it mean to be British?' is it reasonable to expect a national consensus about 'FBVS, what they mean and how they should be taught to young children and then tested in schools? It is not easy to find quick answers which all teachers and parents would agree upon. 


\section{Inclusion and Disability Studies}

Studies about disability often emphasise the need for Inclusion. Sometimes it is assumed that 'inclusion' is about including disability, and is concerned mainly with addressing the educational rights of children and young people who have special educational needs'. Discussions about disability in this context include physical disability and also learning differences. This highlights the opposite positions suggested by the medical and social models of disability (Smith, 2008). Disabled people have not been given the respect and rights they deserve, and it can be seen that so many years after the Salamanca Agreement (UNESCO, 1994), although attitudes are changing, they are changing extremely slowly. The question of accepting disability and special needs as part of a whole range of normal human experience has not been resolved. This dilemma emerges in debates about whether or not children with special educational needs should be included in main stream classes, or educated separately (Cigman, 2006). Questions such as whose rights are more important, and whether segregation based on disability should be acceptable to everyone in society, are still being debated.

Barton's insightful sociological contribution to the field of inclusion challenges over-simplification and reductive thinking.

Len (Barton) argued that social exclusion, of which disablism is one element, (1) has many compounding forms of differing exclusions, (2) is not a natural but a socially constructed process, (3) has no single factor that can remove it and (4) it is in constant need of conceptual analysis. (Goodley \& Runswick-Cole, 2010, p. 273)

The above points defy superficial solutions for challenges to social and educational exclusions. They consider the whole child/young person, rather than identifying someone by their disability alone. This field is contested and politicized. The way schools deal with inclusion can influence democratic processes in what (Slee, 2010) has called the 'politics of possibility' for the whole of the school community.

Writing about disability, and against segregation based on 'ability' Sally Tomlinson (2010) asserts that

Inclusive education is part of the effort to counter the often pointless global struggles for economic dominance, and the encouragement of seemingly endless competition between institutions, teachers, parents and young people. Whatever the cultural, political, social or economic 
differences between countries, every society that aspires to create a decent, humane and effective system of education should think in terms of inclusion. Inclusion is an issue of equity and ethics, human rights and social justice, and also economic improvement. (Tomlinson, 2010, p. 544)

She suggests that there is an argument here not about special educational needs but special educational rights which are deeply embedded in the social model of disability.

A social interpretation of disability argued that whatever a person's perceived impairment, they were further disabled by society's failure to accommodate to their needs. (Tomlinson, 2010, p. 543)

There is an Equalities Act in place now which incorporates previous acts in UK

In UK The Equality Act 2010 legally protects people from discrimination in the workplace and in wider society. It replaced previous anti-discrimination laws with a single Act, making the law easier to understand and strengthening protection in some situations. It sets out the different ways in which it is unlawful to treat someone. (https://www.gov.uk/guidance/ equality-act-2010-guidance)

The extent to which this can be realized in practice, and in the field of education in particular, is open to question and must remain under scrutiny.

\subsection{Intersectionality}

Some groups in society experience multiple forms of disempowerment and oppression and this can lead to higher levels of exclusions. Crenshaw (1989) defines intersectionality as the structures that make certain identities become consequences and the vehicle for vulnerability. Individuals get caught up and are at the receiving end of the way injustices built into the structure of institutions work together to bring about inequality. According to Gillborn (2015) intersectionality is 'multiple forms of inequality and identity and how they inter-relate in different contexts over time'. Conceptually, intersectionality works with the ideas presented above. It works against selecting just one factor e g. gender or ethnicity. Instead, it takes account of how all of these come together to cause inequality in society, and this inequality must be challenged.

Collins' (2017) definition of intersectionality includes many axes of social divisions, how they act together and influence each other through 
(1) racism, sexism, class exploitation and similar systems of oppression are interconnected and mutually construct one another; (2) configurations of social inequalities take form within intersecting oppressions; (3) perceptions of social problems as well reflect how social actors are situated within the power relations of particular historical and social contexts; and (4) because individuals and groups are differently located within intersecting oppressions, they have distinctive standpoints on social phenomena. (Collins \& Bilge, 2016, p. 25)

This explains how some people live at the 'intersection' of many kinds of oppressions which are not of their own making. If we fail to recognize these intersections we will effectively marginalize, ignore and silence those who are most at risk of exclusion. Children and young people from families which live at the intersections of many forms of oppressions are to be found in schools and in other social institutions and organisations.

\section{Social and Educational Inclusion Module}

Taking into account the complex and competing definitions of inclusion and their impact on education and society as defined above, a module on Social and Educational Inclusion was designed at Bath Spa University. This module aims to provide post graduate students with the tools to question and explore inclusion and inclusive education with reference to their own professional and personal experiences. In reality, while trying out ideas and putting this module together at Bath Spa University we found ourselves working face to face with students who had come directly from countries such as Columbia, Ghana, Pakistan, Syria, Venezuela and Zambia. We were also working with students of local British heritage, as well as students whose parents had migrated from countries such as Somalia. They were the first in their families to attend a British university. So the module had to respond to the questions raised from many perspectives and in voices which shared the experiences of living and being educated in many countries. A purely "British" module which only discussed examples of research from Britain just would not work. Students wanted to contribute and learn with their peers through sharing their educational trajectories and life experiences and their own lived realities.

In order for the module about Inclusion and Inclusive Education to be successful and relevant for all our students, it would have to engage with global and international issues. Not to do so would exclude the participation of students and their voices, and that would be counter-productive to 
the overall aims of this module. The questions which formed a fundamental part of this module were of scholarly and research interest to a group of academics. The module was therefore designed to include contributions from more than just one or two academics. This enriched the quality of discourse within the module. We also wanted to work with colleagues outside the university, including charities and NGOS, and to develop other non-university collaborations. The idea would be to invite colleagues to the university for guest lectures, as well as taking students outside the university to become familiar with the ways in which NGOs and other charitable organizations work against exclusion.

A full description of the module which was approved at the university is as follows:

\section{Education for Democratic Intercultural Citizenship \\ Social and Educational Inclusion in Schools and their \\ Communities Bath Spa University}

This is an optional module for Masters and Doctoral students. It is a complementary module for ERASMUS+ students enrolled on EDIC+ (Education for Democratic Intercultural Citizenship) Programme. Students can study one 7.5 ECT module in their own university, plus another 7.5 ECT module in one of the other participating universities. Students might also like to take another optional module in Bath Spa University as well, which may be on offer at the same time as the EDIC module. (Students are normally asked to have 6.5 IELTS - in English to participate in Masters level teaching in the English language at Bath Spa University). IELTS (International English Language Testing System) indicates the level of acceptable competence in English. The level varies according to the academic expectations of a programme. As a Masters level module the IELTS reflect the basic standard of English language required to ensure that the course is easily accessible to all students.

\subsection{Aims}

After completing this module students will be able to

- Demonstrate an understanding of the key ideas about social justice, human rights and social and educational inclusion with particular reference to education. These concepts include exclusion and inclusion, identity, diversity and equity. 
- Engage with sociological and educational debates concerning key notions which have British, European and global implications.

- Become aware of the 'bigger picture' - the challenges and barriers to inclusion socially and educationally and in terms of policy.

- Acquire an understanding of the psychology of social exclusion and inclusion.

- Understand the development of identity and belonging among young people.

- Develop strategies to overcome prejudice and social and educational exclusion.

- Learn from educational professionals who research/work successfully with excluded and marginalised groups, or those with special or additional educational needs, such as minority ethnic groups, refugees, excluded children, gypsy and traveller children.

- Develop inter-disciplinary understanding and a multi-professional approach to encourage inclusion.

- Enhance an understanding of inclusive education with a view to developing a link between conceptual understanding and professional and practical outlook.

- Develop skills of intercultural communication and the ability to work with diversity on an individual basis and with peers from other countries.

\subsection{Teaching}

This module will be taught through lectures, seminars and tutorials. Students will be expected to work collaboratively, and to present their work together in small groups after each section of the module has been taught. The presentations will be based on students' own learning and reflections on what they have gained from reading, lectures, discussions in class and from their own research. The module will have three sections. These are: (i) sociological enquiry, (ii) school/organization-centred approach and (iii) students' own investigation of a topic of personal and professional interest to them.

Students will be expected to write a learning journal throughout the module in which they can record and reflect on ideas obtained from their reading as well as those gained from lectures and seminars with tutors and guest speakers. Formative feedback will be provided for individual presentations in class. This will help students to do a poster presentation which will receive further formative feedback and discussion before they submit their final essays or research-based texts for assessment. The final summative assignment is an essay of 3500 to 4000 words. Students can choose to write either (a) a conceptual paper exploring inclusion or (b) use examples from research and their own 
experiences to explore an aspect of social and educational inclusion in a particular setting/context within their own country or (c) a comparative account of two countries if they have comparative experience and wish to develop a comparative research perspective.

\subsection{Prior Knowledge}

There is no expectation of previous knowledge about this topic. It is assumed that post graduate students will come from diverse backgrounds, and possibly from different countries.

\subsection{Module Content}

This module will look critically at social and educational inclusion, opening up assumptions about the questions of rights, equity and inclusion with regard to many factors such as race/ethnicity, gender, social class and disability. The broad aim of the module is to look at human rights, social justice and the value of intercultural understanding and dialogue, providing students with opportunities to develop social and educational understanding of complex issues. Students will be invited to engage in debate and argument about the dilemmas faced by teachers, their students and the community, to think of ways forward, and to connect these to curriculum-based experiences. These will be considered with reference to policy and practice in a country with which students are familiar. We will work with the professional and personal experiences which students bring, whether these are school based, or youth work/community based, and will consider civic engagement.

The module comprises of three sections:

1. The first section will cover sociological and policy issues. It will encourage debate and develop an understanding of the key concepts - ideas about empowerment, entitlement to education, rights and responsibilities.

2. The second section will focus on the educational and organizational aspects of social and educational inclusion related to research-based findings. These will consider emancipatory research, action research and ethnography.

3. Thirdly, the module will focus on practical skills related to social and educational inclusion. This will mean meeting people who work in the field and visiting voluntary organizations to see how they engage in problem solving in their day-to day work.

\subsection{Context}

Identity is important for all students. Why is it that in some countries e.g.UK those young people who might have considered themselves 'European citizens' 
or 'global citizens', may have to re-configure their identity after Brexit? Is this a real or imagined identity? Where do settlers, new migrants and refugees/ asylum seekers fit in European cities? Are schools helping them to have high aspirations and to make a positive future contribution to society? How can teachers and other education professionals become culturally responsive and equip their students to work confidently with the dominant language? The module will be further enhanced by contributions from visiting speakers. These include local organizations which work with excluded children (Black family support initiatives) statutory organizations and individuals who are responsible for educating children in care for example, and charitable organizations which work with young homeless people and have successfully helped them to obtain admissions in university courses. These professionals will share professional and personal experiences of working creatively with the challenges of inclusion and diversity, and help develop a deeper understanding of social and educational inclusion.

\subsection{Assessment}

Formative Assessment will involve individual presentation in class which will receive feedback. This will help students to produce a poster based on reading and experience of education in their own country/a country with which they are familiar OR they can choose to present a comparative account of two countries if they have relevant experience they wish to develop further. Students can explore how organizations are working to include young people socially and educationally. Feedback will be provided to help with summative assessment.

Summative Assessment will be an essay or a short empirical research based study of what is happening in the field, either with individuals or in an organization which is trying to work in an inclusive and innovative way with groups who find themselves on the margins of society. These can be for example refugee families, people with disabilities, young people who have English as an additional language, and are therefore educationally disadvantaged. More recently the needs of children of school going age and young people with mental illness have been acknowledged in UK and are receiving attention.

The Module at Bath Spa University is a collaboration between several academics. Their joint contribution will strengthen what the module has to offer future post graduate students.

\subsection{Students' Perceptions and Feedback on the Module}

Before being finalized the module was trialled in the university. We thought it would be useful to find out how students reacted to the try out module, and to 
see what they made of what we were trying to do in the class. What could we do better next time? Was there something we should do differently, and if so, what and how? Should we find a better way to connect different sessions? Was it a good or bad idea to involve many academics in the teaching of this module rather than just one or two people? We had to reassure all students that they could say anything they liked and that their critical feedback would be used to improve the final shape of the module as it appears below. Of course they did not have to take part if they did not want to. When introducing the idea of research and seeking informed consent and inviting students to take part in evaluation one of the key readings used in the IP in Charles University Prague was Morwenna Griffith's (2003) essay on empowerment. Other students in subsequent IPs were also informed of this text which explains why their voices are important and how their ideas would be shared. The students in the try out module were asked to read Griffith's text as a starting point for a conversation before they began to evaluate it. This text seems to work whenever it is used with students. They realize what they have to say really matters, and that it will be taken seriously.

The questions students were invited to respond to were about each session and also how the whole course held together for them. Did it hold together well, and if not, then what more should we do to make it better?

At the very outset students were invited to write a daily learning journal in which they could address the following questions as prompts. They could write about other related matters as well in addition to these questions which were initially developed to document students' experiences of IPs held at Charles University Prague in 2017 and then used again at the Universities of Tallinn and Helsinki in 2018.

1. What were the 2 things (enjoyable and different) to what I'm used to?

2. What I found challenging and why?

3. What did I learn from my peers?

4. What did I contribute?

5. What did I learn about myself as a student and a researcher?

We received feedback from two trials of try out modules in Bath Spa University which were held in June 2018 and then again in January 2019. Different students attended these try out modules each time. This was because the Masters students who attended in June 2018 had completed their degrees by the time the second try out module ran. Some had left the university. Some of the doctoral students who attended the try out module in June 2018 were either busy doing field work, or they had other commitments. All the students who attended the January 2019 try out module were Masters students. On both occasions students were taught by at least six academics. The feedback from the students has helped to shape the module, which is planned to be offered 
at Bath Spa University in the future. The schedule of that module can be found after the presentation of students' feedback.

\subsubsection{Summary of Student Feedback}

The students appreciated and enjoyed learning about the different topics related to Inclusion and Inclusive Education. Some had heard or read about Inclusion before, whereas others had not. So the class had to create a level playing field for all students where no one would feel excluded, nor feel that they did not know enough, or that they did not belong in the group. In this situation the opening session was quite important as it set the ground rules and made it possible for the students to be introduced to each other. The teaching by different lecturers was highly valued, as it provided the students with an opportunity to interact with academics they had not met before. It also inspired students to read the research these colleagues were doing, or had done in the past. One criticism was that the students would have liked to meet all the lecturers again some three or four weeks later, so that they could continue the conversations after they had read more about the topics introduced by each speaker. This would have been difficult to arrange after the end of the course, though we did think about the possibility of organising IP style roundtables in the future, and also introducing a social event bringing all academics and students together in the last session.

International students added a lot to the modules because they questioned Eurocentric research and sometimes the data which was different from what they might have found if they researched the same topic in their own schools or in their own countries. On the whole they were happy to share the experiences from their own perspectives and their own countries. However, this was more likely to happen if there was a group of students who knew each other from another programme and had previous knowledge about each other's professional background or research interests. Some students had not met each other and initially they thought all the other students were more knowledgeable about Inclusion than they themselves were.

Some of the comments from the students are as follows:

\section{Personal Knowledge and Course Content}

I was very moved to hear about the journey of a lecturer from where he started to where he is now. Leadership and equity is a very complicated thing.

I had never thought seriously about how some children face so much bullying and that is why they don't go to school. This is because of their accent, or colour or social class. That the difference between home and school can break a child's wish to learn. 
Critical race theory is something I knew nothing about. I am white I guess (Irish heritage) so I heard about white privilege for the first time and found it uncomfortable ... that it can cause inequality.

Issues about disability are very challenging. So, how kindly a society deals with disability tells us how civilized a society is.

\subsubsection{Module Structure}

It was good to have a lecture $10 a m$ to 12 and another one from 1 to $3 \mathrm{pm}$. It kept us all together for lunch break. A longer gap would maybe lose some people?

I wish we could have some trips to go to outside Bath that were connected to the module ... like a cultural visit. A combination of work and fun?

A lecture each morning and a workshop every afternoon may work well. Two lectures a day are too much to study in a new topic.

Based on what the students said and what was possible we came up with the schedule of a module. This is presented below.

\section{Schedule EDIC+ Course Bath Spa University}

\section{Social and Educational Inclusion}

Module Leader: Ghazala Bhatti

Contributors: Prof Martin Levinson, Prof Charlotte Chadderton, Dr Mahmoud Emira, Dr Jim Hordern, Dr Chloe Yeh, Richard Parker, Caroline Kuhn \& Shaun Taylor

Day 1

AM: Introduction - (ice breakers)

Dr Ghazala Bhatti - What is inclusion? An introduction to the module Introducing different meanings of inclusion: social justice, intersectionality, human rights

PM: Case study - what does inclusion look like? (research evidence) 
Evidence presented in published research will be used in this session to interrogate the idea of inclusion and what has been reported about different topics which this module covers.

\section{Day 2}

AM: Prof Martin Levinson - Bridges and Barriers: the challenge of inclusion This session will explore the interface between education and cultural identities, considering conflicting values/aspirations encountered in home and school contexts

PM: Richard Parker - Exclusion from school and society

PM: Specific examples of research about supporting different groups of vulnerable young people at school will be considered, such as potential and actual impact of approaches geared to improving schools' awareness of children and young people's needs. These include emotional needs around attachment, as well as critiques of such approaches.

\section{Day 3}

AM: Prof Charlotte Chadderton - Critical Race Pedagogies

This session will critically examine race and will consider its implications for education

PM: visit: Centre for Black Family support

\section{Day 4}

AM: Dr Jim Hordern - Pedagogic rights? Participation, enhancement and inclusion in education

This session will examine the issue of pedagogic rights (enhancement, inclusion and participation) as the basis for a democratic and inclusive society.

\section{PM: Ghazala Bhatti - Language Matters}

This session will look at the ways in which language and identity are linked, and how for example not knowing English can lead to disengagement with education in an English speaking country.

\section{Day 5}

AM: Dr Chloe Yeh - The Psychology of Prejudice and Inclusion Prejudice is something which is age old. Why do we have prejudices and how do we make sense of the world?

PM: Workshop: Student led discussion on a topic about inclusion -formative assessment 
This is planned to help students connect the theory of inclusion with their own particular topic of interest, which they can explore further in class to obtain critical and supportive feedback from their peers and tutor.

\section{Day 6}

Saturday - Cultural visit Pitt Rivers Museum of Anthropology, Oxford. Sunday - No classes

\section{Day 7}

AM: Dr Mahmoud Emira - Leadership and Inequality in Education: problematising inclusion?

This session will discuss inclusion and inequality from a leadership perspective. It will highlight inequality that individuals from underrepresented groups (e.g. disabled) experience when aiming to engage in leadership and how they can be supported.

PM: Student poster presentation in seminar - further development from Day 5 (formative assessment with feedback)

This is planned to help develop the initial ideas which were tried and tested during the workshop on Day 5 . Students will be invited to put together a poster which represents their ideas, which they can present in class to their peers. They should be prepared to answer questions about the topic they are presenting. This is a formative assessment which should help the students to write the essays for the summative assessment after the end of the module.

\section{Day 8}

AM: Shaun Taylor - On social class \& transitions

Transitions mark a change, a step in another direction. How do schools manage transitions and how do children experience them? Are some people excluded and others included?

PM: Workshop using real data gathered from home \& school

\section{Day 9}

AM: Caroline Kuhn - Educational journeys and lifelong learning This session will look at how inequality affects education systems: the case of Venezuela. Venezuela has the biggest reserve of natural gas in the world and one of the biggest reserves of oil. Yet $90 \%$ of the population lives in poverty. For a majority education is a luxury. 


\section{Day 10}

AM: Guest speaker from psychology department on vulnerability \& artistic expressions

PM: Learning disability and inclusion lecture: dyslexia \& autism

Not supporting students with learning difficulties can lead to their exclusion from school and exclusion from society. This session will look at learning disability /learning differences

AM: Round table with lead tutor

PM: Dr Ghazala Bhatti - tutorial support for summative assessment.

\section{Day 11}

AM: Library day

PM: End of course

The organizations which are linked to this module and which are located outside the university are as follows:

- mentoring plus, http://mentoringplus.net/

- supported housing - Bath based

- www.ndti.org.uk

\subsection{Literature for the Module}

Clough, P. \& Corbett, J. (2006). Theories of inclusive education. London: Paul Chapman. Emira, M., Brewster, S., Duncan, N., \& Clifford, A. (2018). What disability? I am a leader! Understanding leadership in HE from a disability perspective. Educational Management Administration and Leadership, 46(3), 457-473.

Frandji, D., \& Vitale, P. (2016). The enigma of Bernstein's pedagogic rights. In P. Vitale \& B. Exley (Eds.), Pedagogic rights and democratic education: Bernsteinian explorations of curriculum, pedagogy and assessment (pp. 13-32). London: Routledge.

Gillborn, D. (2015). Intersectionality, critical race theory, and the primacy of tacism: race, class, gender, and disability in Education. Qualitative Inquiry, 21(3), 277-287.

Griffiths, M. (2003). Action for social justice in education. BuckinghAM: Open University Press.

Hamilton, P. (2018). School books or wedding dresses? Examining the cultural dissonance experienced by young gypsy/traveller women in secondary education. Gender and Education, 30(7), 829-845.

Hordern, J. (2019). Higher expertise, pedagogic rights and the post-truth society. Teaching in Higher Education, 24(3), 288-301.

Lucey, H. \& Reay, D. (2010). Identities in transition: Anxiety and excitement in the move to secondary school. Oxford Review of Education, 26(2), 191-205.

Rogoff, B. (2003). The cultural nature of human development. Oxford: Oxford University Press. 


\section{$5 \quad$ Concluding Remarks: What Are the Challenges for Inclusion?}

The field of education is constantly changing in response to the events that shape or question the meaning of inclusion. To return to the main topic of this chapter: how can we continue to work for inclusion and for inclusive education? This will be debated in the module offered at Bath Spa University to the students who will attend it to discuss social justice issues, and most importantly by the academics who teach it.

\section{References}

Allan, J. (2005). Inclusion as an ethical project. In S. Tremain (Ed.), Foucault and the government of disability (pp. 281-297). Ann Arbor, MI: Michigan: University of Michigan Press.

Bhatti, G., \& Leeman, Y. (2011). Convening a network within the European conference on educational research. European Educational Research Journal, 10(1), 129-142.

Blackledge, A., \& Creese, A. (2010). Multilingualism: A critical perspective. London: Bloomsbury.

Cigman, R. (Ed.). (2006). Included or excluded? The challenge of the mainstream for some SEN children. London: Routledge.

Collins, P. (2017). The difference that power makes: Intersectionality and participatory democracy. Feminist Review, 8(1), 19-39.

Collins, P., \& Bilge, S. (2016). Intersectionality. Cambridge: Polity Press.

Crenshaw, K. (1989). Demarginalizing the intersection of race and sex: A Black feminist critique of anti discrimination doctrine, feminist theory and antiracist politics. Chicago, IL: University of Chicago Legal Forum.

DfE (Department for Education). (2014). Promoting fundamental British values as Part of SMSC in schools. London: Department for Education.

Gobbo, F. (2009). Moving lives: A reflective account of a three generation travelling attractionist family in Italy. In P. Danahar, M. Kenny, \& J. Leder (Eds.), Traveller, nomadic and migrant education (pp. 13-28). London: Routledge.

Goodley, D., \& Runswick-Cole, K. (2010). Len Barton, inclusion and critical disability studies: Theorising disabled childhoods. International Studies in Sociology of Education, 20(4), 273-29o.

Gillborn, D. (2015). Intersectionality, critical race theory, and the primacy of racism: Race, class, gender and disability in education. Qualitative Inquiry, 27(3), 277-287.

Griffiths, M. (2003). Action for social justice in education. Buckingham: Open University Press.

Home Office. (2011). Preventing extremism: The prevent strategy. London: The Home Office. 
Hoque, A. (2015). British-Islamic identity: Third generation Bangladeshis from east London. London: ioE Press.

Jackson, R. (2006). Should the state fund faith-based schools: A review of arguments. British Journal of Religious Education, 25(2), 89-102.

Janmaat, J. (2018). Educational Influences on young people's support for fundamental British values. British Educational Research Journal, 44(2), 251-273.

Lander, V. (2016). Introduction to fundamental British values. Journal of Education for Teachers, 42(3), 274-279.

Levinson, M., \& Hooley, N. (2014). Supporting the learning of nomadic communities across transnational contexts: Exploring parallels in the education of UK Roma gypsies and indigenous Australians. Research Papers in Education, 29(4), 373-389.

McEachron, G., \& Bhatti, G. (2015). Teaching English as an additional language in the global classroom: A transnational study in the United States and United Kingdom. Global Education Review, 2(2), 59-83.

Osler, A., \& Starkey, H. (2010). Teachers and human rights education. Stoke-on-Trent: Trentham.

Osman, R. (2015). Forward. In E. Walton \& S. Moonsamy (Eds.), Making education inclusive (pp. ix-x). Newcastle-upon-Tyne: Cambridge Scholars Publishing.

Panjwani, F. (2016). Towards an overlapping consensus: Muslim teachers' views on fundamental British values. Journal of Education for Teaching, 42(3), 329-340.

Sant, E., \& Hanley, C. (2018). Political assumptions underlying pedagogies of national education: The case of student teachers teaching 'British values' in England. British Educational Research Journal, 44(2), 319-337.

Sen, A. (1980). Equality of what? In S. Murrin (Ed.), The Tanner lectures on human values. Salt Lake City, UT: University of Utah Press.

Sen, A. (1993). Capability and well being. In M. Nussbaum \& A. Sen (Eds.), The quality of life (pp. 1-6). Oxford: Clarendon Press.

Short, G. (2002). Faith based schools: A threat to social cohesion? Journal of Philosophy of Education, 36(4), 559-572.

Slee, R. (2010). Driven to the margins, disabled students, inclusive schooling and the politics of possibility. Cambridge Journal of Education, 31(3), 385-397.

Smith, S. (2008). Social justice and disability: Competing interpretations of the medical and social model. In K. Kristiansen, S. Vehmas, \& T. Shakespeare (Eds.), Arguing about disability (pp. 1-15). London: Routledge.

Taras, R. (2013). Islamophobia never stands still: Race, religion and culture. Ethnic and Racial Studies, 36(3), 417-433.

Tomlinson, S. (2010). A tribute to Len Barton. British Journal of Sociology of Education, $31(5), 537-546$.

Tomlinson, S. (2015). Fundamental British values. In C. Alexander, D. Weekes-Bernard, \& J. Arday (Eds.), The Runnymede school report: Race, education and inequality in contemporary Britain (pp. 10-13). London: Runnymede Trust. 
UNESCO. (1994). Salamanca statement and framework for action on special needs education. Paris: UNESCO.

UNESCO. (2016). Sustainable development goals: leaving no one behind: How far on the way to universal primary and secondary education? Paris: UNESCO.

Young, I. (1990).Justice and the politics of difference. Princeton, NJ: Princeton University Press.

Young, I. (1996). Communication and the other: Beyond deliberative democracy. In S. Benhabib (Ed.), Democracy and difference: contesting the boundaries of the political. Princeton, NJ: Princeton University Press. 